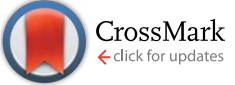

Cite this: RSC Adv., 2017, 7, 3179
Received 7th November 2016 Accepted 11th December 2016

DOI: 10.1039/c6ra26409c

www.rsc.org/advances

\section{Synthesis and antibiofouling properties of crosslinkable copolymers grafted with fluorinated aromatic side chains $\uparrow$}

\begin{abstract}
Pengcheng Zhu, Weidong Meng and Yangen Huang*
To obtain highly effective antifouling coatings, a series of functional ternary copolymers grafted with short fluoroalkyl or perfluoropolyether modified fluorinated aromatic side chains and cross-linkable functional groups were prepared via radical polymerization. Nuclear magnetic resonance (NMR), Fourier transform infrared (FT-IR), gel permeation chromatography (GPC), X-ray photoelectron spectroscopy (XPS) and thermogravimetric analysis (TGA) were used to characterize the fluoropolymers. The surface properties of the fluoropolymer coatings on cotton fabric, aluminum plates and glass slides were studied. The results indicate that the fluoropolymers show good thermal stabilities $\left(T_{d}>303{ }^{\circ} \mathrm{C}\right)$, and the hydrophobicity of the fluoropolymer coatings was increased with the increase of fluorinated monomer content (water contact angle on cotton fabric was up to $144^{\circ}$ ). The antifouling characteristics were investigated by Escherichia coli and Staphylococcus aureus attachment studies. The fluoropolymers exhibited excellent antibacterial activity against E. coli and S. Aureus. The fluoropolymers might be used as promising environmentally benign marine antifouling coating materials due to their high thermal stability, hydrophobicity and antifouling effect.
\end{abstract}

\section{Introduction}

Marine biofouling arises from the adhesion of macroorganisms, bacteria and microalgae on artificial surfaces such as ship hulls, and results in many problems, including increased fuel consumption and maintenance costs due to corrosion. ${ }^{1}$ Antifouling technologies based on traditional chemical methods, biological methods, and physical methods have been developed over the last few decades. Although chemical methods, including self-polishing coatings based on tributyltin (TBT) or copper pyrithione, are the most effective approaches for prevention of marine biofouling, they have been banned since 2008 due to their serious environmental impacts. ${ }^{2,3}$ Hence, novel environmentally benign solutions to reduce biofouling are being sought with urgency.

Apart from biological methods such as the application of enzymes as antifouling agents, ${ }^{4,5}$ physical methods such as the modification of surface topography, hydrophobic properties, and charge potential to prevent biofouling have been considered the ultimate antifouling solution, because of their broadspectrum effectiveness and zero toxicity. In this regard, the potency of fluoropolymers and silicon elastomers, which have

College of Chemistry, Chemical Engineering and Biotechnology, Donghua University, 2999 North Renmin Road, 201620 Shanghai, China. E-mail: hyg@dhu.edu.cn; Fax: +86-21-67792608

$\dagger$ Electronic supplementary information (ESI) available. See DOI: 10.1039/c6ra26409c been considered as the most promising candidates, have been explained in terms of their low surface energy and interesting mechanical properties. ${ }^{6-8}$ Poly(dimethylsiloxane) (PDMS) elastomers, as the most important nontoxic anti-biofouling coating materials, have been widely used in commercial applications owing to their low modulus and low surface energy. ${ }^{9}$ However, the antifouling efficacy of PDMS marine coatings is not as good as toxic paints, and regular mechanical cleaning (scrubbing) of the coated surface is also required, which increases the operational expense. ${ }^{\mathbf{1 0}}$ In this respect, fluoropolymer, as another class of low surface energy coating materials, showed better antifouling performance compared with PDMS coatings; however, there is also a fatal drawback that these materials often undergo rapid molecular reconstruction in water, and thus lose their fouling release characteristics. ${ }^{11}$ For creating a long-term stable low energy surface, the fluorinated side chain of a polymer should be able to organize into an ordered structure on the surface and at the same time keep a high density of $-\mathrm{CF}_{3}$ groups on the coating surface. ${ }^{12}$ Ober and coworkers found that if a polymer contains semifluorinated alkyl substituted aromatic side chains $\left(-\mathrm{C}_{6}\right.$ $\left.\mathrm{H}_{5} \mathrm{CH}_{2} \mathrm{O}\left(\mathrm{CH}_{2}\right)_{m}\left(\mathrm{CF}_{2}\right)_{n} \mathrm{~F}, m>1, n>3\right)$, the reconstruction process can be reduced due to the $\pi-\pi$ stacking interactions between aromatic side chains. ${ }^{\mathbf{1 3}}$ Coleen and coworkers reported that the strength of $\pi-\pi$ stacking interactions can be further increased through introduction of fluorine atoms on the benzene ring. ${ }^{14}$ Another method found to be effective for creating a stable, non-reconstructable coating was to restrict 
chain mobility of the polymer through chemical cross-linking groups, such as epoxide functional groups. ${ }^{15}$

In this paper, we designed and synthesized a series of functional ternary copolymers grafted with short fluoroalkyl or perfluoropolyether modified fluorinated aromatic side chains and cross-linkable functional groups. Usually, for achieving a low energy surface, perfluoroalkyl chains $\left(\mathrm{C}_{n} \mathrm{~F}_{2 n+1}, n>8\right)$ and their derivatives are the most favorable functional groups. ${ }^{\mathbf{1 6 , 1 7}}$ However, recent studies suggest that molecules containing perfluoroalkyl chains $\left(\mathrm{C}_{n} \mathrm{~F}_{2 n+1}, n>8\right)$ are relatively lipophilic and can accumulate in wildlife and the human body, which results in a potential risk to human health and environmental concerns. The introduction of fluorine atoms on the benzene ring avoids the use of long perfluoroalkyl chains $\left(\mathrm{C}_{n} \mathrm{~F}_{2 n+1}, n>8\right)$ while keeping the high fluorine content, and the stability of the low energy surface is increased via increased $\pi-\pi$ stacking interactions between aromatic side chains. The low energy surfaces were fabricated on cotton fabric, aluminum plates and glass slides, and characterized by X-ray photoelectron spectroscopy (XPS). The antifouling properties of the crosslinked fluoropolymer coatings on aluminum plates to Escherichia coli and Staphylococcus aureus have been investigated.

\section{Experimental section}

\subsection{Materials}

2,3,4,5,6-Pentafluorostyrene was purchased from TCI (Shanghai, China). 1H,1H-Heptadecafluoro(2,5-dimethyl-3,6dioxanonan-1-ol) and $1 H, 1 H, 2 H, 2 H$-perfluorooctanol were purchased from Qinba Chemical Scientific Ltd. Methyl methacrylate (MMA), glycidyl methacrylate (GMA) and other chemicals were purchased from Sinopharm Chemical Reagent Co. Ltd and used as received.

\subsection{Measurements}

NMR spectra were recorded at ambient temperature on a Bruker AV400 spectrometer at 400.0 and $377.0 \mathrm{MHz}$ for ${ }^{1} \mathrm{H}$ and ${ }^{19} \mathrm{~F}$ nuclei, respectively. Tetramethylsilane (TMS) was applied as the internal chemical shift reference for ${ }^{1} \mathrm{H}$ NMR spectra and $\mathrm{CFCl}_{3}$ as an external standard for ${ }^{19} \mathrm{~F}$ NMR spectra, downfield shifts are designated as positive. Fourier transform infrared (FT-IR) spectra were recorded on a FT-IR spectrometer (Avatar 380) using $\mathrm{KBr}$ crystals in the infrared region of $4000-400 \mathrm{~cm}^{-1}$.

Molecular weights and distributions were determined by gel permeation chromatography (GPC) using a series of three linear Styragel columns. A Waters 1515 pump and Waters 2414 differential refractive index (RI) detector (set at $35{ }^{\circ} \mathrm{C}$ ) were used. A commercial calibration kit of polystyrene standards was utilized to calibrate the GPC elution traces. As a result, the molecular weights $\left(M_{\mathrm{w}}, M_{\mathrm{n}}\right)$ and their distributions were thus evaluated.

Thermogravimetric analysis (TGA) was carried out under a $\mathrm{N}_{2}$ atmosphere with a heating rate of $10{ }^{\circ} \mathrm{C} \min ^{-1}$, up to $600{ }^{\circ} \mathrm{C}$, using a Netzsch TG 209 F1 analyzer.

The water contact angle (CA) was measured using automatic video contact-angle testing apparatus (DataPhysics OCA 40,
DataPhysics Instruments $\mathrm{GmbH}$, Germany). The probe liquid was deionized water. The average CA value was determined by measuring five different positions of the same sample with $5 \mu \mathrm{L}$ each time. Drops were fitted with a Young-Laplace formula to calculate the static contact angle.

X-ray photoelectron spectroscopy (XPS) measurements were taken with a Kratos XSAM-800 using an AlK $\alpha$ X-ray source, and a pass energy of $40 \mathrm{eV}$. The X-ray gun was operated with a Mono Al anode, $15 \mathrm{keV}$ voltage and $20 \mathrm{~mA}$ current. The analyzer chamber pressure was in the $10^{-9}$ Torr range.

The bacterial attachment was assessed using a scanning electron microscope (HITACHI/TM-1000).

Treatment of the cotton fabric with the polymers. The desized, bleached and cleaned cotton fabrics $(3 \mathrm{~cm} \times 3 \mathrm{~cm})$ were soaked in the polymer solution $\left(0.002 \mathrm{~g} \mathrm{~mL}^{-1}\right.$, THF as solvent) for $2 \mathrm{~h}$. The cotton fabrics were dried at $80^{\circ} \mathrm{C}$ for $30 \mathrm{~min}$ and then cured at $160{ }^{\circ} \mathrm{C}$ for $3 \mathrm{~min}$. Thereafter the cotton fabrics were cooled in a dryer.

Biofouling assays. The biofouling properties of the copolymer film were investigated using $E$. coli and $S$. aureus as the model microorganisms. Basically, E. coli and $S$. aureus were incubated in Luria-Bertani (LB) and Nutrient Broth (NB) liquid culture medium, respectively. Both strains were shaken at $37{ }^{\circ} \mathrm{C}$ for $24 \mathrm{~h}$, and then diluted with the same liquid culture medium to a predetermined concentration (around $2.0 \times 10^{5} \mathrm{cfu} \mathrm{mL}^{-1}$ ), using the standard dilution method. All the polymer films coated on the aluminum sheets were sterilized at $121{ }^{\circ} \mathrm{C}$ for $30 \mathrm{~min}$. Aluminum sheets were first put into separate culture plates containing $4 \mathrm{~mL}$ of $E$. coli suspension or $S$. aureus suspension, and then into a shaking incubator at $37^{\circ} \mathrm{C}$ for $24 \mathrm{~h}$. Then, these films were washed with sterile saline in order to remove dead cells and residuals, and then fixed with $2.5 \%$ glutaraldehyde solution at $0{ }^{\circ} \mathrm{C}$ for $2 \mathrm{~h}$. All the films were dehydrated successively using 30\%, 50\%, 70\%, 90\%, 95\% and $100 \%$ ethanol solution at room temperature for 10 minutes. Finally, the films were dried in a vacuum oven overnight and were scanned using an electron microscope.

\subsection{Synthesis}

Synthesis of monomer (1a). $1 H, 1 H, 2 H, 2 H$-Perfluorooctanol $(2.4 \mathrm{~g}, 6.6 \mathrm{mmol})$ was added dropwise to a solution of $\mathrm{NaH}$ $(0.26 \mathrm{~g}, 6.6 \mathrm{mmol})$ in THF $(40 \mathrm{~mL})$ under a nitrogen atmosphere. The reaction mixture was stirred for $1 \mathrm{~h}$ at room temperature, then a solution of 2,3,4,5,6-pentafluorostyrene (1.2 g, $6 \mathrm{mmol})$ in THF (15 mL) was added slowly at $0{ }^{\circ} \mathrm{C}$. After stirring for $1 \mathrm{~h}$ at $0{ }^{\circ} \mathrm{C}$, the reaction mixture was brought to reflux for $19 \mathrm{~h}$ and cooled to room temperature. The reaction was quenched with ice water $(40 \mathrm{~mL})$, and the reaction mixture was extracted with ethyl acetate $(50 \mathrm{~mL} \times 3)$. The combined organic layer was washed with brine $(20 \mathrm{~mL})$, dried over anhydrous $\mathrm{MgSO}_{4}$, filtered, evaporated, and the residue was purified by column chromatography (silica gel, petroleum ether) to yield pure 1a as a colorless liquid. ${ }^{18}$ (2.16 g, 67\% yield), ${ }^{1} \mathrm{H}$ NMR $(400 \mathrm{MHz}$, $\left.\mathrm{CDCl}_{3}\right) \delta(\mathrm{ppm}): 6.66(\mathrm{dd}, J=18.0,11.9 \mathrm{~Hz}, 1 \mathrm{H}), 6.08(\mathrm{~d}, J=$ $18.0 \mathrm{~Hz}, 1 \mathrm{H}), 5.69$ (d, $J=11.9 \mathrm{~Hz}, 1 \mathrm{H}), 4.53(\mathrm{t}, J=6.7 \mathrm{~Hz}, 2 \mathrm{H})$, 2.79-2.60 (m, 2H). $\left.{ }^{19} \mathrm{~F} \mathrm{NMR} \mathrm{(377} \mathrm{MHz,} \mathrm{CDCl}_{3}\right) \delta(\mathrm{ppm}):-80.8(\mathrm{t}$, 
$J=10.3 \mathrm{~Hz}, 3 \mathrm{~F}),-113.4(\mathrm{dt}, J=33.5,18.5 \mathrm{~Hz}, 2 \mathrm{~F}),-121.9(\mathrm{~s}, 2 \mathrm{~F})$, -122.9 (s, 2F), -123.5 (s, 2F), -126.0 to -126.4 (m, 2F), -144.4 (dd, $J=22.1,10.0 \mathrm{~Hz}, 2 \mathrm{~F}),-158.1$ (dd, $J=21.8,9.7 \mathrm{~Hz}, 2 \mathrm{~F}$ ). IR $\left(\mathrm{KBr}, \mathrm{cm}^{-1}\right)$ : 2976, 2923, 1648, 1489, 1408, 1235, 1190, 1144, 1123. MS (ESI): $m / z 539[\mathrm{M}+\mathrm{H}]^{+}$. HRMS (ESI-TOF): $m / z[\mathrm{M}+\mathrm{H}]^{+}$ calcd for $\mathrm{C}_{16} \mathrm{H}_{8} \mathrm{~F}_{17} \mathrm{O}$ : 539.0298; found: 539.0297 .

Synthesis of monomer (1b). Colorless liquid. (90\% yield), ${ }^{1} \mathrm{H}$ NMR (400 MHz, $\left.\mathrm{CDCl}_{3}\right) \delta(\mathrm{ppm}): 6.64(\mathrm{dd}, J=18.0,11.9 \mathrm{~Hz}, 1 \mathrm{H})$, $6.09(\mathrm{~d}, J=18.0 \mathrm{~Hz}, 1 \mathrm{H}), 5.70(\mathrm{~d}, J=11.9 \mathrm{~Hz}, 1 \mathrm{H}), 4.72(\mathrm{~d}, J=$ $10.0 \mathrm{~Hz}, 2 \mathrm{H}) .{ }^{19} \mathrm{~F}$ NMR $\left(377 \mathrm{MHz}, \mathrm{CDCl}_{3}\right) \delta$ (ppm): -80.2 to $-83.3(\mathrm{~m}, 13 \mathrm{~F}),-130.0$ to $-130.6(\mathrm{~m}, 2 \mathrm{~F}),-134.2$ to $-136.2(\mathrm{~m}$, $1 \mathrm{~F}),-144.0$ to $-144.6(\mathrm{~m}, 2 \mathrm{~F}),-145.1$ to $-145.9(\mathrm{~m}, 1 \mathrm{~F}),-157.7$ to $-160.4(\mathrm{~m}, 2 \mathrm{~F})$. IR (KBr, $\left.\mathrm{cm}^{-1}\right): 2953,2922,1647,1492,1306$, 1229, 1198, 1150, 1126. MS (ESI): $m / z 657$ [M + H] $]^{+}$. HRMS (ESITOF): $m / z[M+H]^{+}$calcd for $\mathrm{C}_{17} \mathrm{H}_{6} \mathrm{~F}_{21} \mathrm{O}_{3}$ : 656.9976; found: 656.9975 .

General procedure for copolymerization. To a $25 \mathrm{~mL}$ threenecked round-bottomed flask equipped with a reflux condenser were added MMA (1.0 g, $10.0 \mathrm{mmol})$, GMA (1.0 g, 7.7 $\mathrm{mmol})$, $1 \mathrm{a}(1.0 \mathrm{~g}, 1.9 \mathrm{mmol}, 33 \mathrm{wt} \%)$, AIBN (0.03 g, $0.2 \mathrm{mmol})$ and THF $(10 \mathrm{~mL})$ under a nitrogen atmosphere. After reflux for $24 \mathrm{~h}$ at $65{ }^{\circ} \mathrm{C}$, the reaction mixture was added dropwise into ethanol $(600 \mathrm{~mL})$ with vigorous agitation. The precipitate was collected by filtration and re-dissolved in ethyl acetate, and reprecipitated in ethanol. This purification process was repeated three times. The product was dried in a vacuum oven overnight to afford polymer $2 \mathrm{a}$ as a white solid $(2.52 \mathrm{~g}, 84 \%$ yield $) .{ }^{19}{ }^{1} \mathrm{H}$ NMR (400 MHz, $\mathrm{CDCl}_{3}$ ) $\delta(\mathrm{ppm}): 4.31-4.46$ (br), 3.78, 3.60, 3.22, $2.85,2.64,1.84,1.44,0.88-1.25$ (br). ${ }^{19} \mathrm{~F} \mathrm{NMR}\left(377 \mathrm{MHz}, \mathrm{CDCl}_{3}\right.$ ) $\delta(\mathrm{ppm}):-80.7(\mathrm{~s}, 3 \mathrm{~F}),-113.3(\mathrm{~s}, 2 \mathrm{~F}),-121.8(\mathrm{~s}, 2 \mathrm{~F}),-122.8(\mathrm{~s}$, $2 \mathrm{~F}),-123.5(\mathrm{~s}, 2 \mathrm{~F}),-126.1(\mathrm{~s}, 2 \mathrm{~F}),-139.4$ to $-143.7(\mathrm{~m}, 2 \mathrm{~F})$, -154.3 to $-159.0(\mathrm{~m}, 2 \mathrm{~F})$. IR $\left(\mathrm{KBr}, \mathrm{cm}^{-1}\right)$ : 2996, 2955, 1728, 1652, 1492, 1239, 1196, 1145.

Polymer $\mathbf{2 b - 2 e}$ were prepared following a similar procedure to that used for $2 \mathrm{a}$, but the amount of MMA was kept constant, and the mass fraction of $1 \mathrm{a}$ was controlled as $20 \mathrm{wt} \%, 10 \mathrm{wt} \%, 5$ wt $\%, 0$ wt $\%$ to get polymer 2 b ( $83 \%$ yield), 2 c ( $83 \%$ yield), 2 d (83\% yield), 2e (87\% yield), respectively. Polymers $2 a-2 e$ were all white solids.

Polymer $\mathbf{2 f - 2 i}$ were prepared following a similar procedure to that used for 2a, but the amount of MMA was kept constant, and the mass fraction of $\mathbf{1 b}$ was controlled as $33 \mathrm{wt} \%, 20 \mathrm{wt} \%, 10$ wt $\%, 5$ wt $\%$ to get 2 f ( $81 \%$ yield), 2 g ( $83 \%$ yield), $2 \mathbf{h}$ ( $82 \%$ yield), $2 \mathbf{i}$ ( $84 \%$ yield), respectively. Polymers $2 \mathrm{f}-2 \mathrm{i}$ were all white solids.

Preparation of polymer-coated surfaces. The fluoropolymer 2a (1 g) and WPAG336 (1.5 wt\% relative to polymer) were dissolved in ethyl ketone $(4 \mathrm{~mL})$ to get a clear, homogeneous solution. The solution was evenly spread onto a piece of glass cleaned using hot piranha solution $\left(\mathrm{H}_{2} \mathrm{SO}_{4}(98 \mathrm{wt} \%): \mathrm{H}_{2} \mathrm{O}_{2}\right.$ $(30 \mathrm{wt} \%)=7: 3 \mathrm{v} / \mathrm{v})$ using spin coating machine. The solution was allowed to evaporate for $10 \mathrm{~min}$, then underwent UV irradiation using a mercury arc lamp for $20 \mathrm{~min}$, followed by a post-exposure bake at $120{ }^{\circ} \mathrm{C}$ for $6 \mathrm{~h}$ until curing was complete. Thus the surface fluoropolymer-coated with 2 a was prepared. Other polymer-coated surfaces on glass were prepared according to the same process by using fluoropolymer $\mathbf{2 b - 2 i}$, respectively. The fluoropolymer-coated surfaces on aluminum sheets were also prepared according to a similar process.

\section{Synthesis of controlled monomer}

Synthesis of compound 4. 4-Hydroxybenzaldehyde (0.49 g, 4.0 $\mathrm{mmol}$ ), triflate 3 (2.3 g, $4.8 \mathrm{mmol}), \mathrm{Cs}_{2} \mathrm{CO}_{3}(2.0 \mathrm{~g}, 6.0 \mathrm{mmol})$, and DMF $(8 \mathrm{~mL})$ were added to a $50 \mathrm{~mL}$ reaction tube under a nitrogen atmosphere at $25^{\circ} \mathrm{C}$. The reaction mixture was stirred for $12 \mathrm{~h}$ and then diluted with water, followed by extraction with ethyl acetate. The organic layer was washed with brine, and dried with anhydrous $\mathrm{MgSO}_{4}$. The combined ethyl acetate layers were concentrated under vacuum, and the residue was purified by column chromatography on silica gel (petroleum ether : ethyl acetate $=10: 1)$ to afford $4(1.348 \mathrm{~g}, 72 \%$ yield $)$ as a white powder. ${ }^{1} \mathrm{H}$ NMR (400 MHz, $\left.\mathrm{CDCl}_{3}\right) \delta(\mathrm{ppm}): 9.93(\mathrm{~s}, 1 \mathrm{H}), 7.89$ (d, $J=7.7 \mathrm{~Hz}, 2 \mathrm{H}), 7.05$ (d, $J=7.8 \mathrm{~Hz}, 2 \mathrm{H}), 4.39$ (t, $J=6.6 \mathrm{~Hz}, 2 \mathrm{H})$, 2.81-2.56 (m, 2H). ${ }^{19} \mathrm{~F} \mathrm{NMR}\left(377 \mathrm{MHz}, \mathrm{CDCl}_{3}\right) \delta(\mathrm{ppm}):-80.7(\mathrm{t}$, $J=11.4 \mathrm{~Hz}, 3 \mathrm{~F}),-113.3(\mathrm{dt}, J=36.6,18.1 \mathrm{~Hz}, 2 \mathrm{~F}),-121.8(\mathrm{~s}, 1 \mathrm{H})$, $-122.8(\mathrm{~s}, 2 \mathrm{~F}),-123.5(\mathrm{~s}, 2 \mathrm{~F}),-125.6$ to $-126.6(\mathrm{~m}, 2 \mathrm{~F})$. IR $(\mathrm{KBr}$, $\left.\mathrm{cm}^{-1}\right):$ 2738, 1693, 1504, 1239, 1200, 1146.

Synthesis of compound 1c. To a $50 \mathrm{~mL}$ three-necked flask were added $\mathrm{Ph}_{3} \mathrm{PCH}_{3} \mathrm{Br}(1.4 \mathrm{~g}, 4 \mathrm{mmol})$ and $\mathrm{THF}(22 \mathrm{~mL})$ under a nitrogen atmosphere. Then $n$-BuLi $(1.6 \mathrm{~mL}, 2.5 \mathrm{M}$ in THF, 4 mmol) was added dropwise to the solution at $-78{ }^{\circ} \mathrm{C}$, and the mixture was stirred at $-78{ }^{\circ} \mathrm{C}$ for $3 \mathrm{~h}$. Following this, a solution of compound 4 (0.94 g, $2 \mathrm{mmol})$ in THF $(4 \mathrm{~mL})$ was added dropwise to the mixture at $-78{ }^{\circ} \mathrm{C}$. The cooling bath was removed after the addition, and the reaction mixture was stirred for $2 \mathrm{~h}$, during which time the temperature increased slowly from $-78{ }^{\circ} \mathrm{C}$ to room temperature. Thereafter, water was added into the reaction mixture and then extracted with diethyl ether. The organic layer was washed with brine, and dried with anhydrous $\mathrm{MgSO}_{4}$. The residue was purified by flash chromatography (petroleum ether) to give compound 1c $(0.842 \mathrm{~g}, 90 \%$ yield) as a yellowish solid. ${ }^{1} \mathrm{H}$ NMR $\left(400 \mathrm{MHz} \mathrm{CDCl}_{3}\right) \delta(\mathrm{ppm})$ : $7.39(\mathrm{~d}, J=8.6 \mathrm{~Hz}, 2 \mathrm{H}), 6.89$ (d, $J=8.6 \mathrm{~Hz}, 2 \mathrm{H}), 6.69(\mathrm{dd}, J=$ $17.6,10.9 \mathrm{~Hz}, 1 \mathrm{H}), 5.66$ (d, $J=17.6 \mathrm{~Hz}, 1 \mathrm{H}), 5.18$ (d, $J=10.9 \mathrm{~Hz}$, $1 \mathrm{H}), 4.31(\mathrm{t}, J=6.8 \mathrm{~Hz}, 2 \mathrm{H}), 2.66(\mathrm{tt}, J=18.4,6.8 \mathrm{~Hz}, 2 \mathrm{H}) .{ }^{19} \mathrm{~F}$ NMR (377 MHz, $\left.\mathrm{CDCl}_{3}\right) \delta(\mathrm{ppm}):-80.7(\mathrm{t}, J=9.9 \mathrm{~Hz}, 3 \mathrm{~F}),-113.2$ to $-113.4(\mathrm{~m}, 2 \mathrm{~F}),-121(\mathrm{~s}, 2 \mathrm{~F}),-122.8(\mathrm{~s}, 2 \mathrm{~F}),-123.5(\mathrm{~s}, 2 \mathrm{~F})$, -126.0 to $-126.2(\mathrm{~m}, 2 \mathrm{~F})$. IR $\left(\mathrm{KBr}, \mathrm{cm}^{-1}\right)$ : 2969, 2928, 1607, 1514, 1405, 1234, 1177, 1137. Analytical data are consistent with that in the literature. ${ }^{20}$

Synthesis of controlled polymer $\mathbf{5}$. The controlled polymer $\mathbf{5}$ was synthesized to explore the influence of fluorine atoms on the benzene ring. Polymer 5 was prepared as a white solid (72\% yield) according to the procedure used for the preparation of $2 \mathbf{a}$. ${ }^{1} \mathrm{H}$ NMR (400 MHz, $\mathrm{CDCl}_{3}$ ) $\delta$ (ppm): 6.95, 6.75, 4.23-3.61 (br), $3.81,3.62,3.25,2.87,2.66,1.85,0.87-1.40$ (br). ${ }^{19} \mathrm{~F}$ NMR (377 $\left.\mathrm{MHz}, \mathrm{CDCl}_{3}\right) \delta(\mathrm{ppm}):-80.7(\mathrm{~s}, 3 \mathrm{~F}),-113.4(\mathrm{~s}, 2 \mathrm{~F}),-121.9(\mathrm{~s}$, $2 \mathrm{~F}),-122.9(\mathrm{~s}, 2 \mathrm{~F}),-123.6(\mathrm{~s}, 2 \mathrm{~F}),-126.2(\mathrm{~s}, 2 \mathrm{~F}) . \mathrm{IR}\left(\mathrm{KBr}, \mathrm{cm}^{-1}\right)$ : 2998, 2949, 1726, 1237, 1196, 1144.

\section{Results and discussion}

\subsection{Synthesis and characterization}

In this work, we focused on developing stable and highperformance low surface energy materials as antifouling 
<smiles>C=Cc1c(F)c(F)c(F)c(F)c1CC(=O)N[Mg]</smiles><smiles>[R]Oc1c(F)c(F)c(C=C)c(F)c1F</smiles>

$\mathrm{Rf}=-\mathrm{CH}_{2} \mathrm{CH}_{2}\left(\mathrm{CF}_{2}\right)_{5} \mathrm{CF}_{3}$ $\mathrm{Rf}=-\mathrm{CH}_{2}\left(\mathrm{CF}\left(\mathrm{CF}_{3}\right) \mathrm{OCF}_{2}\right)_{2} \mathrm{CF}_{2} \mathrm{CF}_{3} \quad$ 1b<smiles>[R]OC(=O)OCc1cc(C=O)ccc1O</smiles><smiles>COc1ccc(C=O)cc1</smiles>

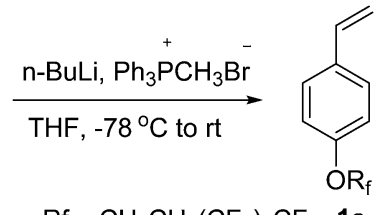

$\mathrm{Rf}=\mathrm{CH}_{2} \mathrm{CH}_{2}\left(\mathrm{CF}_{2}\right)_{5} \mathrm{CF}_{3}$ 1c

Scheme 1 Synthesis of fluorinated monomers $1 \mathrm{a}, 1 \mathrm{~b}$ and $1 \mathrm{c}$.

finishing agents. The strategy was to combine the advantages of perfluoroalkane or perfluoropolyether, 2,3,4,5,6-pentafluorostyrene and epoxy pendant groups to prepare crosslinkable fluoropolymers. The fluorinated monomers $\mathbf{1 a}$ and 1b contain fluorinated aromatic side chains grafted with short fluoroalkyl and perfluoropolyether groups, respectively, and were used to prepare the copolymers with low surface energies. The choice of methylmethacrylate (MMA) as the principal component should enable the tuning of the matrix's mechanical behaviour by adjusting the glass transition temperature ${ }^{21}$ and GMA provides a cross-linkage via the ring-opening reaction of epoxy pendant groups. The fluorinated monomers $\mathbf{1 a}$ and $\mathbf{1 b}$ were prepared by nucleophilic substitution of 2,3,4,5,6-pentafluorostyrene with corresponding fluorinated alcohols in the presence of sodium hydride (Scheme 1). The radical copolymerization of the fluorinated monomers, MMA and GMA, was accomplished in the presence of radical initiator AIBN under a nitrogen atmosphere (Scheme 2). A series of terpolymers were synthesized with various stoichiometries of the fluorinecontaining monomers $(0,5,10,20,33$, wt $\%$ relative to total weight of monomers), MMA and GMA (Tables 1 and 2). Antifouling surfaces with cross-linked fluroropolymers were obtained by ring-opening reaction of epoxy pendant groups,
Table 1 Composition and yields of fluoropolymers $2 \mathrm{a}-2 \mathrm{~d}$ and 5

\begin{tabular}{llllll}
\hline Polymers & $\mathbf{1 a}(\mathrm{g})$ & MMA $(\mathrm{g})$ & GMA $(\mathrm{g})$ & $\begin{array}{l}\mathbf{1 a} \\
(\mathrm{wt} \%)\end{array}$ & Yield (\%) \\
\hline $\mathbf{2 a}$ & 1 & 1 & 1 & 33 & 84 \\
$\mathbf{2 b}$ & 0.6 & 1 & 1.4 & 20 & 83 \\
$\mathbf{2 c}$ & 0.3 & 1 & 1.7 & 10 & 83 \\
$\mathbf{2 d}$ & 0.15 & 1 & 1.85 & 5 & 83 \\
$\mathbf{5}$ & 1 & 1 & 1 & 33 & 72
\end{tabular}

Table 2 Composition and yields of fluoropolymers $2 \mathrm{e}-2 \mathrm{i}$

\begin{tabular}{llllll}
\hline & & & & $\mathbf{1 b}$ & \\
Polymers & MMA $(\mathrm{g})$ & $\mathbf{1 b}(\mathrm{g})$ & GMA $(\mathrm{g})$ & $(\mathrm{wt} \%)$ & Yield (\%) \\
\hline $\mathbf{2 f}$ & 1 & 1 & 1 & 33 & 81 \\
$\mathbf{2 g}$ & 1 & 0.6 & 1.4 & 20 & 83 \\
$\mathbf{2 h}$ & 1 & 0.3 & 1.7 & 10 & 82 \\
$\mathbf{2 i}$ & 1 & 0.15 & 1.85 & 5 & 84 \\
$\mathbf{2 e}$ & 1 & 0 & 2 & 0 & 87
\end{tabular}

catalyzed by an organic acid under an UV lamp (Scheme 3). In order to explore the influence of fluorine atoms on the benzene ring, controlled polymer $\mathbf{5}$ was synthesized with normal perfluoroalkyl substituted styrene 1c as a fluorinated monomer (Scheme 1).

The chemical structure and composition of the fluoropolymers were characterized by ${ }^{1} \mathrm{H}$ NMR, ${ }^{19} \mathrm{~F}$ NMR and FTIR analyses. The ${ }^{1} \mathrm{H}$ NMR spectra of $\mathbf{1 a}$ and $\mathbf{2 a}$ are shown in Fig. 1, in which the signals are attributed to the corresponding protons marked with letters. Proton signals at 6.66, 6.08 and $5.69 \mathrm{ppm}$ in the ${ }^{1} \mathrm{H}$ NMR spectrum of $1 \mathrm{a}$ can be assigned to the $\mathrm{CH}_{2}=\mathrm{CH}-$ group, and these signals disappeared and new signals are presented at 0.86-1.44 ppm in that of $2 \mathrm{a}$, which demonstrated the successful incorporation of 1a in the polymerization under initiation of AIBN. Meanwhile, the ${ }^{19} \mathrm{~F}$ NMR spectra of $1 \mathbf{a}$ and $2 \mathbf{a}$ are almost the same (Fig. 2). Similar results can be seen for monomer $\mathbf{1 b}$ and polymer $\mathbf{2 b}$, as shown in Fig. 3 and 4 . The results indicated

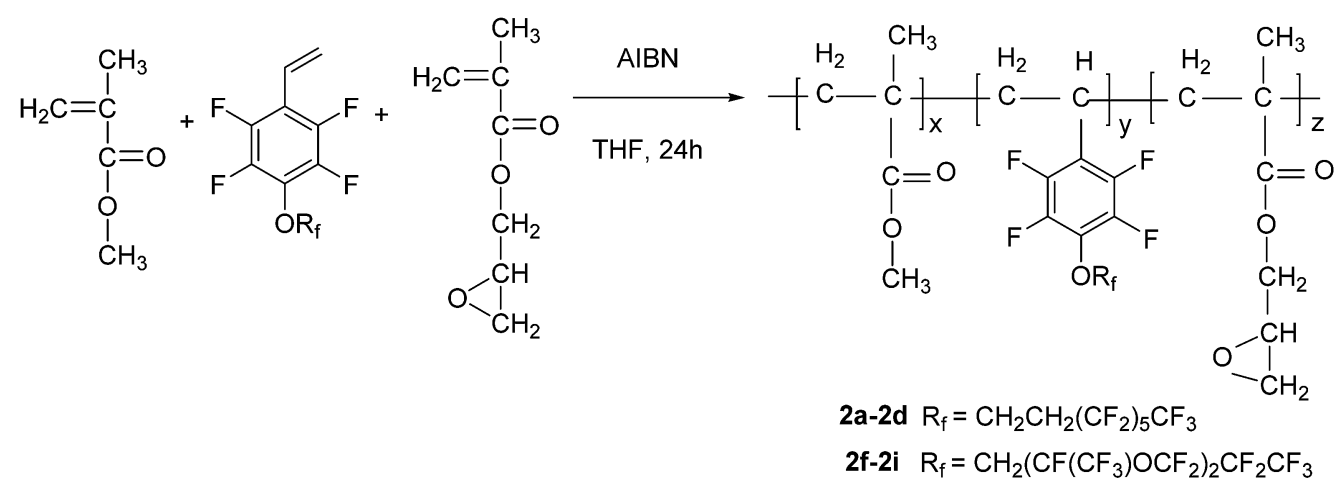

Scheme 2 Synthesis of fluoropolymers. 


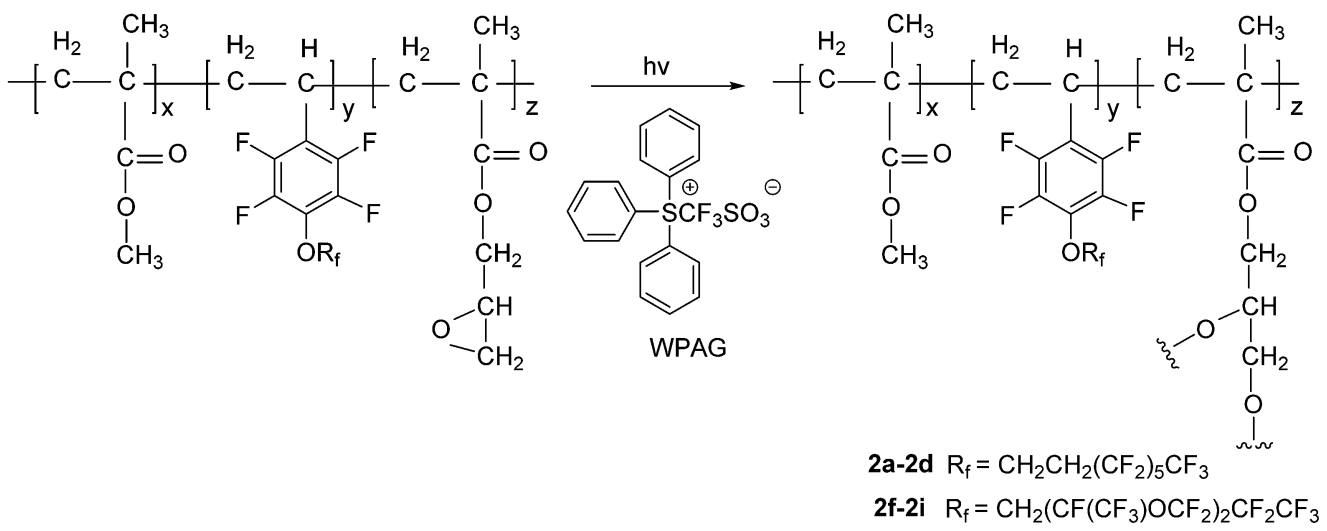

Scheme 3 The acid-catalyzed photolytic epoxide ring-opening cure chemistry.

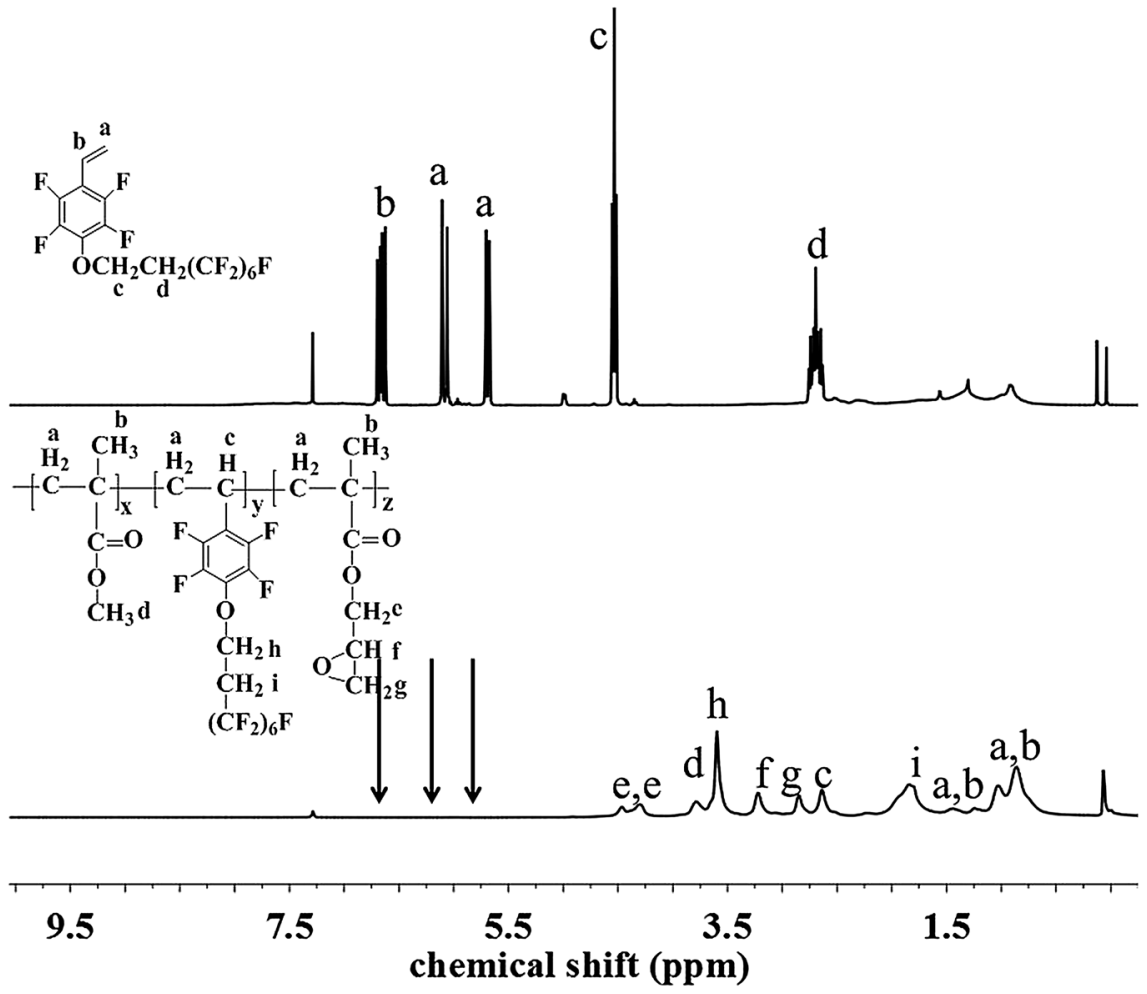

Fig. $1{ }^{1} \mathrm{H}$ NMR spectra of monomer $1 \mathrm{a}$ and polymer $2 \mathrm{a}$.

that radical polymerization reactions were successfully conducted.

The FT-IR spectra of monomers $\mathbf{1 a}$ and $\mathbf{1 b}$, and corresponding fluoropolymers $\mathbf{2 a}$ and $\mathbf{2 f}$ are presented in Fig. 5. In addition to the characteristic absorption bands of $\mathrm{C}-\mathrm{F}$ bonds around $1145 \mathrm{~cm}^{-1}$ and $1239 \mathrm{~cm}^{-1}$, there were also characteristic absorption bands of the $\mathrm{C}-\mathrm{H}$ stretch $\left(2922-2976 \mathrm{~cm}^{-1}\right), \mathrm{C}=\mathrm{C}$ stretch $\left(1648 \mathrm{~cm}^{-1}\right)$ and aromatic bands $\left(1493 \mathrm{~cm}^{-1}\right)$ for monomers $\mathbf{1 a}$ and $\mathbf{1 b}$. The disappearance of the characteristic absorption of $\mathrm{C}=\mathrm{C}\left(1648 \mathrm{~cm}^{-1}\right)$ from the spectra of fluoropolymers $2 \mathbf{a}$ and $\mathbf{2 f}$ indicates that the fluorinated monomers were transferred into the polymers. In the FT-IR spectra of fluoropolymers $\mathbf{2 a}$ and $\mathbf{2 f}$, the strong absorption band around 1728 $\mathrm{cm}^{-1}$ is attributed to carbonyl stretching vibrations. There were also characteristic absorption bands of the $\mathrm{C}-\mathrm{F}$ stretch around $1145 \mathrm{~cm}^{-1}$ and $1239 \mathrm{~cm}^{-1}$. So we can conclude that the polymers are successfully synthesized with fluorinated styrene 1a or 1b, MMA and GMA as monomers via free radical polymerization.

\subsection{Thermal properties}

All polymers exhibit good solubility in general solvents such as $\mathrm{CH}_{2} \mathrm{Cl}_{2}$, THF, ethyl acetate, acetone, and so on. As shown in Tables 3 and 4 , the molecular weights $\left(M_{\mathrm{w}}\right)$ of the polymers measured by GPC are higher than $3.0 \times 10^{4} \mathrm{~g} \mathrm{~mol}^{-1}$. 


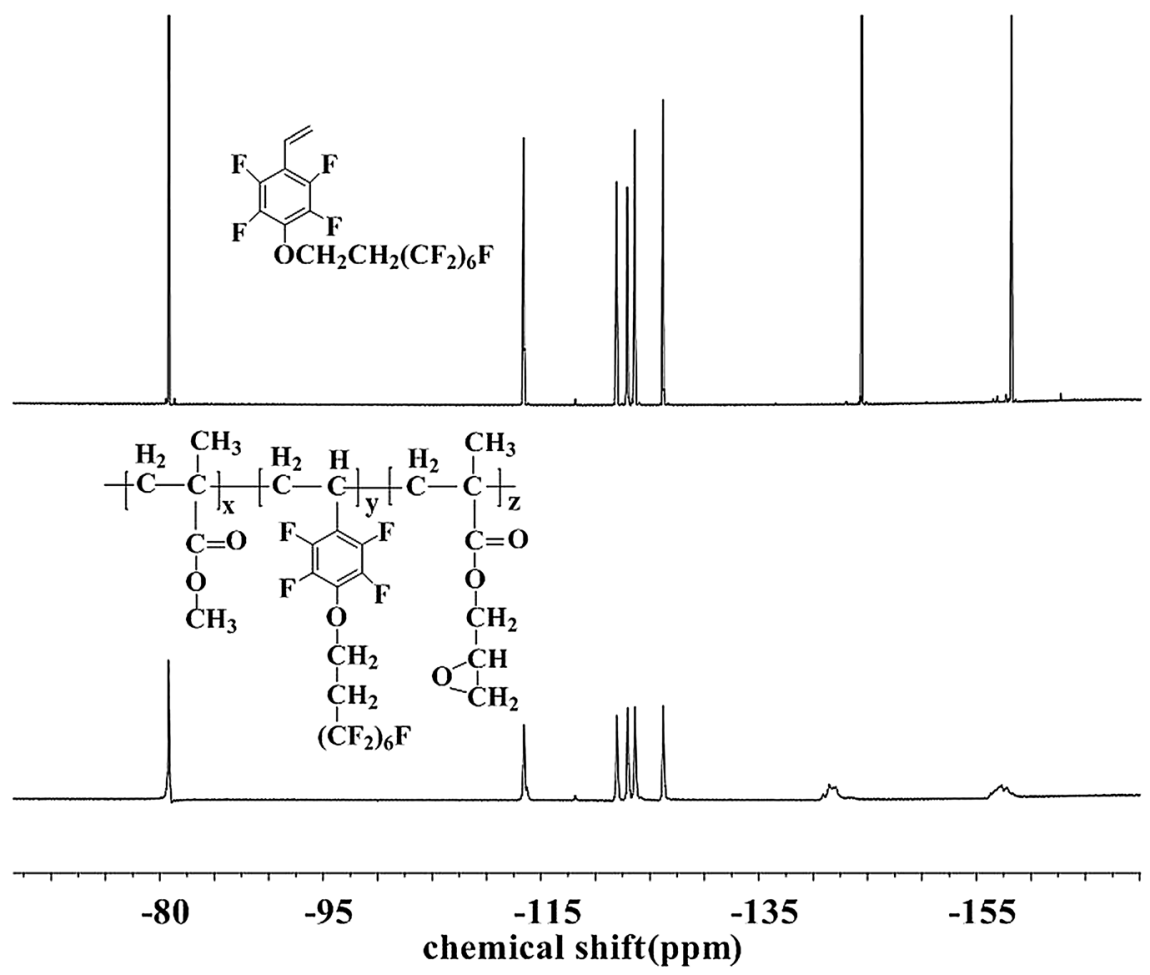

Fig. $2{ }^{19}$ F NMR spectra of monomer $1 \mathrm{a}$ and polymer $2 \mathrm{a}$.

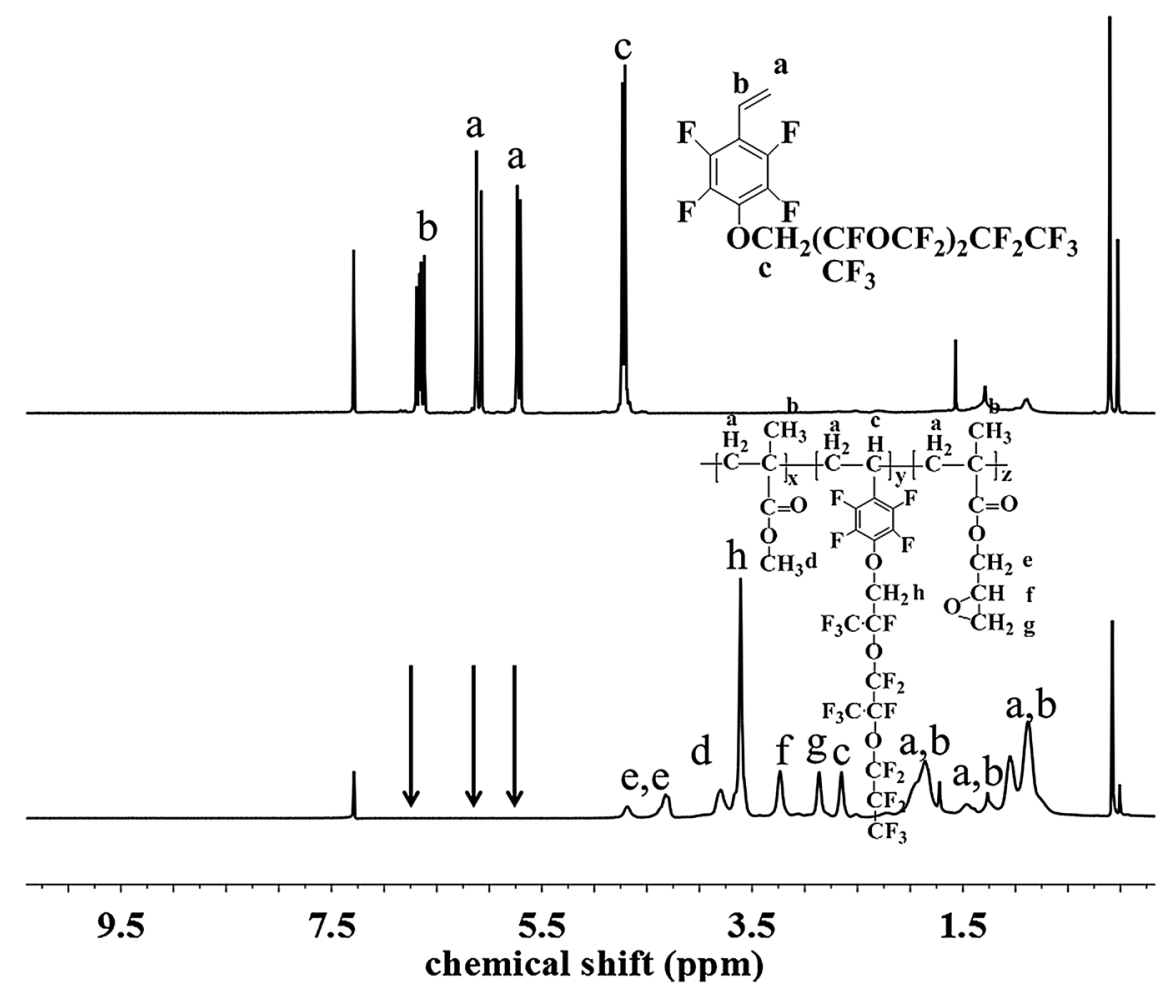

Fig. $3{ }^{1} \mathrm{H}$ NMR spectra of monomer $1 \mathrm{~b}$ and polymer $2 \mathrm{f}$.

As shown in Fig. 6 and 7, Tables 3 and 4, the temperatures of the $10 \%$ weight loss of perfluoroalkyl-substituted polymers $2 \mathbf{a}-$ $\mathbf{2 d}$ and perfluoropolyether-substituted polymers $\mathbf{2 f - 2 \mathbf { i }}$ are similar and in the range of 296 to $314{ }^{\circ} \mathrm{C}$. The onset thermal decomposition temperatures $\left(T_{\mathrm{d}}\right)$ of perfluoroalkyl-substituted polymers $2 \mathbf{a}-2 \mathbf{d}$ were $303{ }^{\circ} \mathrm{C}$ to $315^{\circ} \mathrm{C}$, at the same time those 


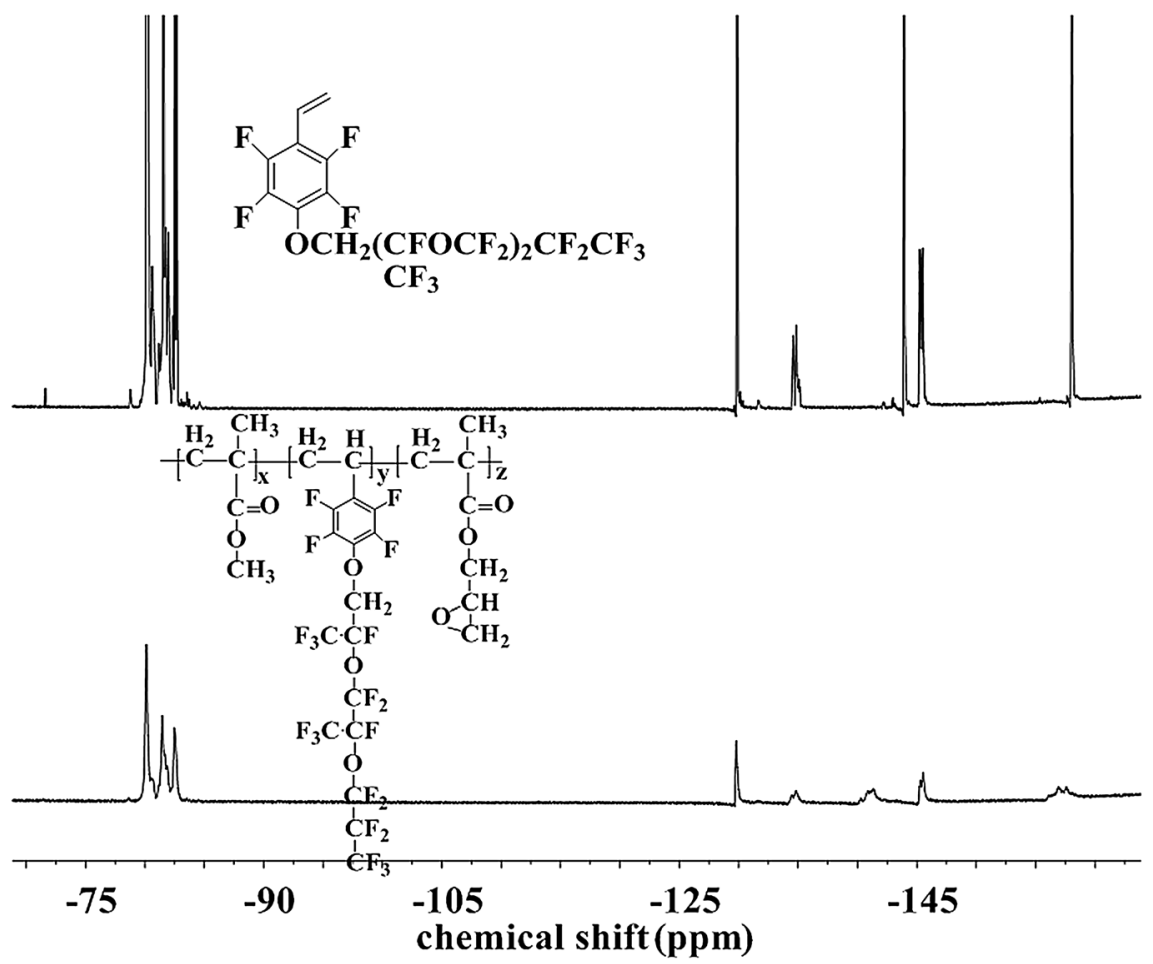

Fig. $4{ }^{19} \mathrm{~F}$ NMR spectra of monomer $1 \mathrm{~b}$ and polymer $2 \mathrm{f}$

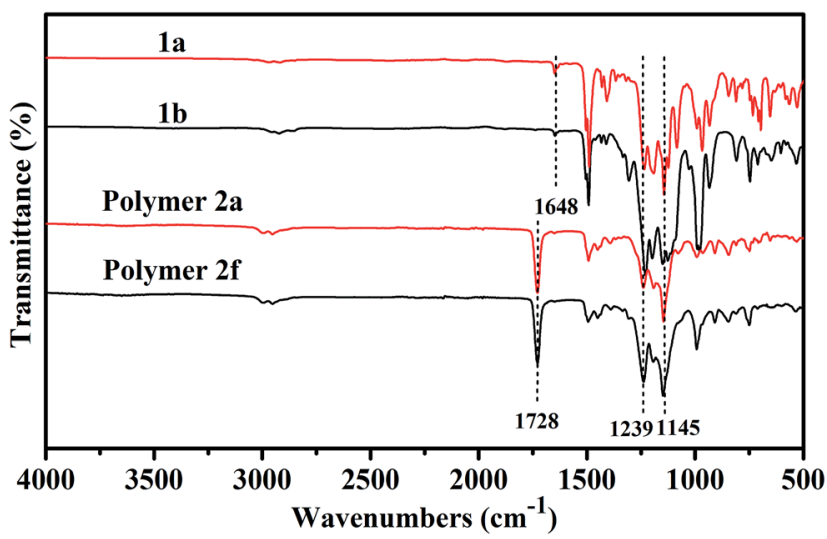

Fig. 5 FT-IR spectra of monomers $1 \mathrm{a}$ and $1 \mathrm{~b}$ and polymers $2 \mathrm{a}$ and $2 \mathrm{f}$.

of perfluoropolyether-substituted polymers $2 \mathbf{f}-2 \mathbf{i}$ were $260^{\circ} \mathrm{C}$ to $332{ }^{\circ} \mathrm{C}$. Surprisingly, the lowest $T_{\mathrm{d}}$ was found for polymer $5(250$ ${ }^{\circ} \mathrm{C}$ ), which contains a nonfluorinated benzene ring, and the highest $T_{\mathrm{d}}$ was achieved for polymer $\mathbf{2 f}$, which contains perfluoropolyether substituted monomer $\mathbf{1 b}$ in a $33 \mathrm{wt} \%$ feeding ratio. The results of thermal analyses demonstrated that these cross-linkable fluoropolymers exhibit good thermal stabilities, which were slightly improved by the incorporation of fluorine atoms on the benzene rings.

It is well known that hydrophobic properties are very important for materials used in marine antifouling. Fluoropolymers $2 \mathbf{a}$ and $\mathbf{2 f}$, with a relatively high fluorine content, were coated on aluminum sheets and glass slides by spin- coating, and then the ring-opening reaction of the epoxy pendant groups was catalyzed by an organic acid under an UV lamp. The water contact angles (CAs) of the resulting coatings were measured, and the average CA of the coatings of $\mathbf{2 a}$ on aluminum sheets and glass slides was $112^{\circ}$ and $109^{\circ}$, respectively, and that for coatings of $2 \mathbf{f}$ was $117^{\circ}$ and $112^{\circ}$, respectively. However, the average CAs for non-fluorinated coatings of $2 \mathbf{e}$ on aluminum sheets and glass slides were only $88^{\circ}$ and $79^{\circ}$, respectively (Table 5). The water contact angles of the polymers on different matrices demonstrated that the surface hydrophobicities of the coatings resulting from the fluorinated polymers are higher than those from the non-fluorinated polymers. Polymers with perfluoropolyether side chains show better surface hydrophobicities than the polymers with perfluoroalkyl side chains.

As is known, if the water CA of a polymer-coated surface is higher than $98^{\circ}$ (surface tension $<25 \mathrm{mN} \mathrm{m}^{-1}$ ), the surface can be classified as an antifouling coating. ${ }^{22}$ In order to study the hydrophobic effect of the synthesized fluoropolymers on other matrices, 2a-2i were coated on cotton fabrics, and then the water contact angles were measured. As shown in Table 5 and Fig. 8, the highest CA on cotton fabric reached $147^{\circ}$ for the perfluoropolyether-substituted polymer $2 \mathbf{f}$ coating, while for the perfluoroalkyl-substituted polymer coating it is $144^{\circ}$. The water contact angles of the polymers increased with the increase of the fluorine content. The average water $\mathrm{CA}$ of the perfluoropolyether-substituted polymer is higher than that of the perfluoroalkyl-substituted polymer, indicating that the former exhibits a lower surface energy than the latter. The water CA of the controlled polymer 5 coating on cotton fabrics is $136^{\circ}$, 
Table 3 Characterization of polymers $2 a-2 d$ and 5

\begin{tabular}{|c|c|c|c|c|c|c|}
\hline Polymers & $\begin{array}{l}\mathbf{1 a} \\
\text { (wt\%) }\end{array}$ & $M_{\mathrm{w}}\left(\times 10^{4} \mathrm{~g} \mathrm{~mol}^{-1}\right)$ & PDI $\left(M_{\mathrm{w}} / M_{\mathrm{n}}\right)$ & $T_{10 \%}{ }^{a}\left({ }^{\circ} \mathrm{C}\right)$ & $T_{\mathrm{d}}^{b}\left({ }^{\circ} \mathrm{C}\right)$ & ${\text { Fluorine } \text { ratio }^{c}(\mathrm{wt} \%)}$ \\
\hline $2 \mathbf{a}$ & 33 & 5.16 & 1.93 & 308 & 303 & 19.91 \\
\hline $2 c$ & 10 & 3.58 & 2.05 & 296 & 304 & 5.27 \\
\hline $2 d$ & 5 & 3.98 & 2.05 & 298 & 315 & 1.96 \\
\hline 5 & 33 & 2.95 & 1.95 & 296 & 250 & 18.3 \\
\hline
\end{tabular}

Table 4 Characterization of polymers $2 \mathrm{e}-2 \mathrm{i}$

\begin{tabular}{|c|c|c|c|c|c|c|}
\hline Polymers & $\begin{array}{l}\text { 1b } \\
\text { (wt\%) }\end{array}$ & $M_{\mathrm{w}}\left(\times 10^{4} \mathrm{~g} \mathrm{~mol}^{-1}\right)$ & $\operatorname{PDI}\left(M_{\mathrm{w}} / M_{\mathrm{n}}\right)$ & $T_{10 \%}{ }^{a}\left({ }^{\circ} \mathrm{C}\right)$ & $T_{\mathrm{d}}^{b}\left({ }^{\circ} \mathrm{C}\right)$ & Fluorine ratio $^{c}(\mathrm{wt} \%)$ \\
\hline $2 f$ & 33 & 4.42 & 2.01 & 314 & 332 & 22.49 \\
\hline $2 \mathrm{~h}$ & 10 & 3.55 & 2.02 & 302 & 260 & 4.75 \\
\hline $2 \mathbf{i}$ & 5 & 3.06 & 2.01 & 296 & 281 & 3.38 \\
\hline $2 e$ & 0 & 1.75 & 1.67 & 292 & 282 & 0 \\
\hline
\end{tabular}

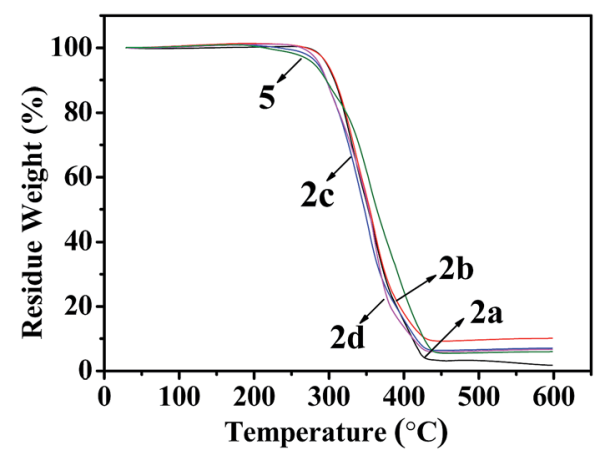

Fig. 6 TGA curves of fluoropolymers $2 a-d$ and 5 .

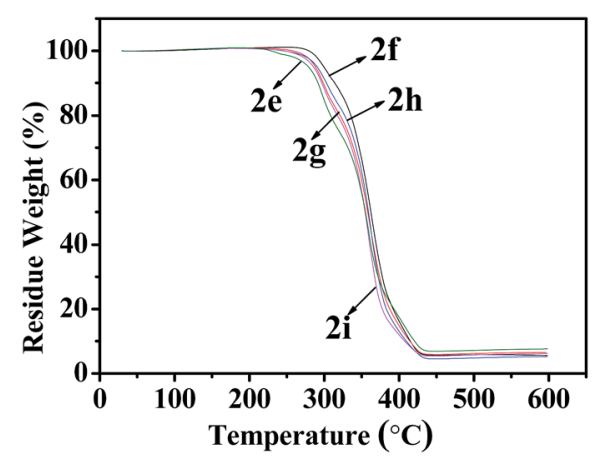

Fig. 7 TGA curves of fluoropolymers $2 \mathrm{e}-2 \mathbf{i}$.

which is $8^{\circ}$ lower than that of polymer $2 a$, indicating that the fluorine atom on the benzene ring improves the hydrophobicity of the polymers.

\subsection{XPS analysis}

Besides hydrophobicity, the antifouling ability of a coating is strongly dependent on other surface characteristics, such as the contribution of different monomers to the surface, morphology, and so on. Therefore, the surface compositions of fluoropolymer coatings were analyzed qualitatively and quantitatively by XPS measurements. As shown in Fig. 9 and 11, the photoemission peaks of F1s, O1s, and C1s are observed at bonding energies of $691 \mathrm{eV}, 535 \mathrm{eV}$ and $288 \mathrm{eV}$, respectively. Fig. 10 and 12 exhibit the XPS of C1s for the fluoropolymer $2 \mathbf{a}$ and $2 \mathrm{f}$ coating surface, the binding energies at $284.8 \mathrm{eV}, 286.4 \mathrm{eV}$, $288.5 \mathrm{eV}, 291.5 \mathrm{eV}$ and $293.4 \mathrm{eV}$ are assigned as $\mathrm{C}=\mathrm{C}, \mathrm{C}-\mathrm{C}, \mathrm{C}-\mathrm{O}$, $\mathrm{O}=\mathrm{C}-\mathrm{O}, \mathrm{CF}_{2}$ and $\mathrm{CF}_{3}$, respectively. The results proved that the polymers have been successfully coated on the slide surface (Fig. 12).

To better explore the influence of fluorine content on the system, the coating surfaces were further studied by quantitative analysis, using the following equation: ${ }^{23}$

$$
C_{i}=\frac{I_{i} / \mathrm{ASF}_{i}}{\sum_{j} I_{j} / \mathrm{ASF}_{j}}
$$

where $C_{i}$ is the percentage of an element, $I_{i}$ is the spectral intensity of an element which is usually expressed by peak area, $\mathrm{ASF}_{i}$ is the sensitive factor of an element (in a Kratos XSAM800 XPS spectrometer, the $\mathrm{F}_{1 \mathrm{~S}}, \mathrm{C}_{1 \mathrm{~S}}$ and $\mathrm{O}_{1 \mathrm{~S}}$ sensitivities were $1,0.25$ and 0.66 respectively). As listed in Table 6, the fluorine content of coating surfaces with fluoropolymer $\mathbf{2 a}$ and 2f was $1.76 \%$ and $5.94 \%$, higher than that of polymer $2 \mathrm{a}$ and 2f, indicating that the fluorine-containing segments enrich the coating surface. 
Table 5 Water contact angles of coatings of fluoropolymers on different matrices

\begin{tabular}{llll}
\hline Polymers & Cotton fabric & Aluminum sheet & Glass slide \\
\hline 2a & $144^{\circ}$ & $112^{\circ}$ & $109^{\circ}$ \\
2f & $147^{\circ}$ & $117^{\circ}$ & $112^{\circ}$ \\
$2 \mathbf{e}$ & $75^{\circ}$ & $88^{\circ}$ & $79^{\circ}$
\end{tabular}

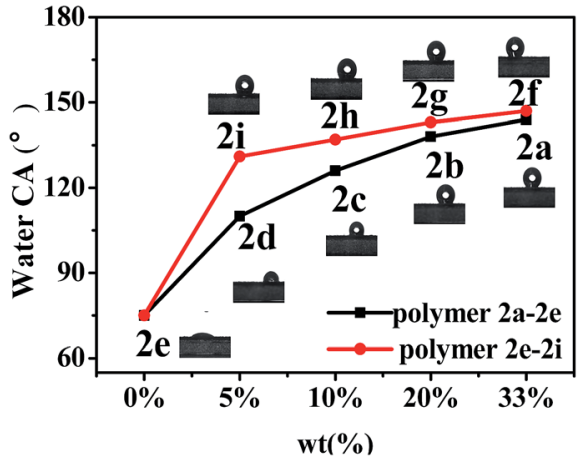

Fig. 8 Water contact angles of coatings of fluoropolymers $2 a-2 i$ on cotton fabrics.

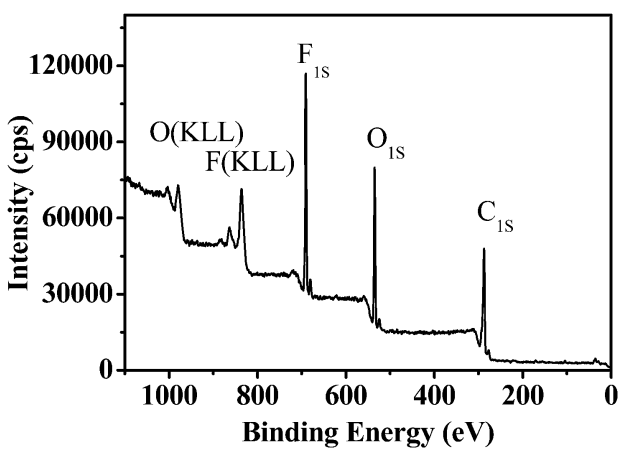

Fig. 9 XPS for the coating surface of fluoropolymer 2a on a glass slide.

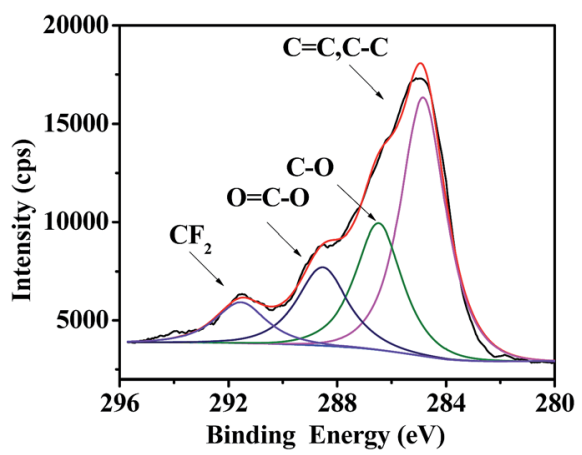

Fig. 10 XPS of C1s for the coating surface of fluoropolymer $2 \mathrm{a}$ on a glass slide.

\subsection{Biofouling assays}

In this study, adhesion assays on Gram-negative (E. coli) and Gram-positive ( $S$. aureus) bacteria were carried out to test whether

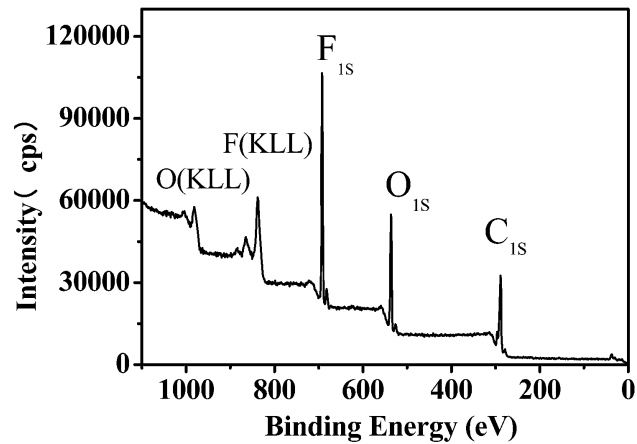

Fig. 11 XPS for the coating surface of fluoropolymer $2 f$ on a glass slide.

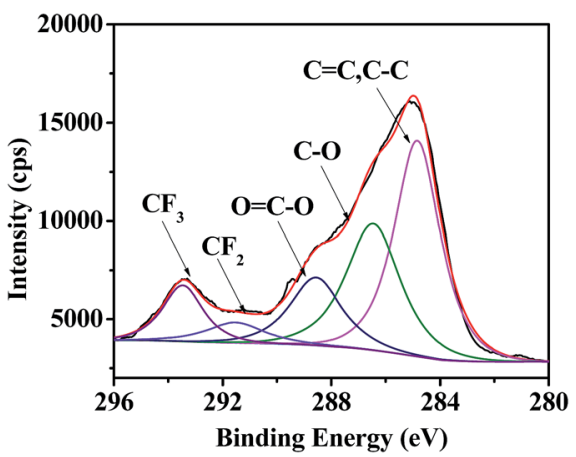

Fig. 12 XPS of C1s for the coating surface of fluoropolymer $2 \mathrm{f}$ on a glass slide.
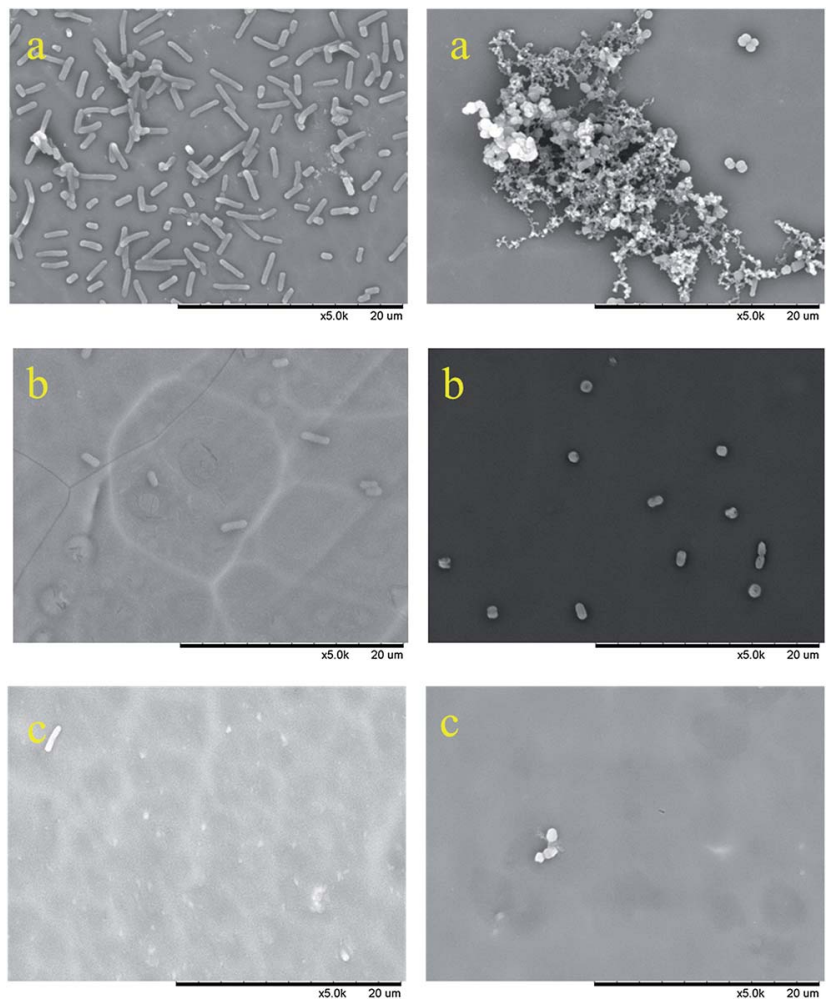

Fig. 13 SEM images of biofouling assay of coatings with E. coli (left) and S. aureus (right), (a) blank sample, (b) polymer $2 \mathrm{i}$, and (c) polymer $2 \mathrm{f}$. 
Table 6 Elemental comparison of coating surfaces with fluoropolymer $2 a$ and $2 f$

\begin{tabular}{lllll}
\hline & \multicolumn{2}{l}{ Elements (\%, XPS) } & \\
\cline { 2 - 4 } Coating surface & $\mathrm{C}(\%)$ & $\mathrm{O}(\%)$ & $\mathrm{F}(\%)$ & Fluorine ratio ${ }^{a}(\%)$ \\
\hline 2a & 55.81 & 22.52 & 21.67 & 19.91 \\
2f & 50.02 & 21.55 & 28.43 & 22.49
\end{tabular}

${ }^{a}$ Fluorine ratio was obtained from elemental analyses.

the fluoropolymer coatings exhibited any antibiofouling effects. ${ }^{24,25}$ Fig. 13a-c represent the biofouling assay with $E$. coli (left) and $S$. aureus (right) on coatings with fluoropolymers containing $0 \%$ of fluorinated monomer (Fig. 13a), $5 \mathrm{wt} \%$ of monomer $\mathbf{1 b}$ (Fig. 13b), $33 \mathrm{wt} \%$ of monomer $\mathbf{1 b}$ (Fig. 13c). As shown in Fig. 13a, a large number of $E$. coli and S. aureus were adhered to the uncoated aluminum plate, while the number of bacteria on the fluoropolymer coated surface is dramatically decreased, as can be seen from Fig. 13b and c. These results indicated that the surface free energy and the adhesion of bacteria on the coating surface are both decreased significantly with the increase of fluorine content in the polymers. Meanwhile, the coatings containing perfluoropolyether chains shows higher antifouling activity than those containing short perfluoroalkyl chains (for the SEM images of biofouling assay of coatings of polymer $\mathbf{2 a}$ and $\mathbf{2 d}$ containing short perfluoroalkyl chains see the ESI, Fig. 39 and $40 \dagger)$. The antifouling ability of the hydrophobic surfaces constructed by the fluoropolymers containing perfluoroalkyl and perfluoropolyether chains can thus be verified.

\section{Conclusions}

Functional cross-linkable fluoropolymers composed of short fluoroalkyl groups or perfluoropolyether substituted fluorinated styrene, MMA and GMA were designed and synthesized through a free radical polymerization. XPS, TGA, contact angle measurements and germ adhesion assays were carried out to explore the surface compositions, thermal stability, hydrophobicity and antifouling ability. The fluoropolymers show good thermal stability. The hydrophobicity of the fluoropolymer coatings is enhanced with the increase of fluorine-containing monomer content in the copolymers. When a fluorine atom is introduced into the benzene ring, the stability and hydrophobicity of the fluoropolymers are slightly improved. In the germ adhesion test, the obtained fluoropolymer coatings exhibit an excellent antifouling ability. The incorporation of different amounts of fluorine-containing monomer into the copolymers reveals the excellent antibacterial activity against $E$. coli and $S$. aureus. Comparing the perfluoropolyether substituted copolymer with the short fluoroalkyl chain substituted copolymer, the former exhibits better thermal stability, hydrophobicity and antifouling effects than the latter. Therefore, in view of environmental concerns, the properties of the coatings containing perfluoropolyether chains meet the standards of green chemistry, and show far-reaching environmentally benign significance.

\section{Acknowledgements}

This work was supported by the Shanghai Municipal Education Commission (No. 13ZZ047) and Fundamental Research Funds for the Central Universities (2232015D3-13).

\section{References}

1 E. Martinelli, D. Gunes, B. M. Wenning, C. K. Ober, J. A. Finlay, M. E. Callow, J. A. Callow, A. D. Fino, A. S. Clare and G. Galli, Biofouling, 2016, 32, 81-93.

2 Y. Zhang, Y. Qi, Z. Zhang and G. Sun, J. Coat. Technol. Res., 2015, 12, 215-223.

3 Q. H. Sun, H. Q. Li, C. Y. Xian, Y. H. Yang, Y. X. Song and P. H. Cong, Appl. Surf. Sci., 2015, 344, 17-26.

4 A. Vaterrodt, B. Thallinger, K. Daumann, D. Koch, G. M. Guebitz and M. Ulbricht, Langmuir, 2016, 32, 1347-1359.

5 M. Zanoni, O. Habimana, J. Amadio and E. Casey, Biotechnol. Bioeng., 2016, 113, 501-512.

6 K. A. Pollack, P. M. Imbesi, J. E. Raymond and K. L. Wooley, ACS Appl. Mater. Interfaces, 2014, 6, 19265-19274.

7 D. Pavlović, S. Lafond, A. Margaillan and C. Bressy, Polym. Chem., 2016, 7, 2652-2664.

8 J. Tan, W. Liu, H. Wang, Y. Sun and S. Wang, J. Appl. Polym. Sci., 2016, 133, 43116.

9 K. S. Kim, N. Gunari, D. MacNeil, J. Finlay, M. Callow, J. Callow and G. C. Walker, ACS Appl. Mater. Interfaces, 2016, 8, 20342-20351.

10 C. J. Kavanagh, R. D. Quinn and G. W. Swain, J. Adhes., 2005, 81, 843-868.

11 J. Zhong, H. Ji, J. Duan, H. Tu and A. Zhang, Colloids Surf., B, 2016, 140, 254-261.

12 J. Tan, W. Liu, H. Wang, Y. Sun and S. Wang, Prog. Org. Coat., 2016, 94, 62-72.

13 X. Li, L. Andruzzi, E. Chiellini, G. Galli, C. K. Ober, A. Hexemer, E. J. Kramer and D. A. Fischer, Macromolecules, 2002, 35, 8078-8087.

14 C. Pugh, C. N. Tang, M. Paz-Pazos, O. Samtani and A. H. Dao, Macromolecules, 2007, 40, 8178-8188.

15 J. C. Yarbrough, J. P. Rolland, J. M. DeSimone, M. E. Callow, J. A. Finlay and J. A. Callow, Macromolecules, 2006, 39, 25212528.

16 G. Galli, D. Barsi, E. Martinelli, A. Glisenti, J. A. Finlay, M. E. Callow and J. A. Callow, $R S C A d v$., 2016, 6, 6712767135.

17 Q. Zhang, Q. Wang, J. Jiang, X. Zhan and F. Chen, Langmuir, 2015, 31, 4752-4760.

18 S. Borkar, K. Jankova, H. W. Siesler and S. Hvilsted, Macromolecules, 2004, 37, 788-794.

19 S. J. Feng, Y. G. Huang, Q. Wang, Y. Gao and F. L. Qing, Polym. Eng. Sci., 2010, 50, 944-951.

20 R. Dorigo, A. M. Garnault, D. Teyssie and S. Boileu, Integration of Fundamental Polymer Science and Technology2, Springer, Netherlands, 1988. pp. 90-93.

21 L. Ruiz, J. G. Hilborn, D. Leonard and H. J. Mathieu, Biomaterials, 1998, 19, 987-998. 
22 Z. K. Hu, J. A. Finlay, L. Chen, D. E. Betts, M. A. Hillmyer, M. E. Callow, J. A. Callow and J. M. DeSimone, Macromolecules, 2009, 42, 6999-7007.

23 Y. Gao, C. L. He, Y. H. Huang and F. L. Qing, Polymer, 2010, 51, 5997-6004.
24 P. Hu, T. Jiang, H. Ni, P. Ye, Z. Han, Z. Zhao, C. Zhu and X. Lu, Polym. Bull., 2016, 73, 1405-1426.

25 X. Chen, G. F. Zhang, Q. H. Zhang, X. L. Zhan and F. Q. Chen, Ind. Eng. Chem. Res., 2015, 54, 3813-3820. 